\title{
Systematic Review and Meta-analysis of Diagnostic Accuracy of Mobile- linked Point-of-Care Diagnostics in Sub-Saharan Africa
}

\author{
Ernest Osei ${ }^{1}$, Sphamandla Josias Nkambule ${ }^{1,3}$, Portia Nelisiwe Vezi ${ }^{1}$, Tivani P. Mashamba- \\ Thompson $^{1,2}$ \\ ${ }^{1}$ Discipline of Public Health Medicine, School of Nursing and Public Health, University of KwaZulu-Natal, \\ Durban, South Africa \\ ${ }^{2}$ Faculty of Health Sciences, University of Pretoria, Prinshof Campus, Pretoria, South Africa \\ ${ }^{3}$ Centre for Health Policy, University of Witwatersrand, Gauteng, South Africa \\ Corresponding Author: Ernest Osei \\ Address: $2^{\text {nd }}$ Floor of George Campbell Building, Department of Public Health Medicine, University of \\ KwaZulu-Natal, Howard College Campus, Durban, 4001, South Africa \\ Email address: ernestosei56@gmail.com \\ Tel: +233242012953 \\ The email address of co-authors \\ Portia Nelisiwe Vezi (mgabadeli999@gmail.com) \\ Sphamandla Josias Nkambule (210501689@stu.ukzn.ac.za) \\ Tivani P. Mashamba-Thompson (tivani.mashamba-thompson@up.ac.za/Mashamba-Thompson@ukzn.ac.za)
}

\begin{abstract}
Mobile health devices are emerging applications that could help deliver point-of-care (POC) diagnosis, particularly in settings with limited laboratory infrastructure, such as sub-Saharan Africa (SSA). The advent of coronavirus has resulted in an increased deployment and use of mHealth-linked POC diagnostics in SSA. We performed a systematic review and meta-analysis to evaluate the accuracy of mobile-linked point-of-care diagnostics in SSA. Our systematic review and meta-analysis were guided by the Preferred Reporting Items requirements for Systematic Reviews and Meta-Analysis (PRISMA). We exhaustively searched PubMed, Science Direct, Google Scholar, MEDLINE, and CINAHL with full-text via EBSCOhost databases from mHealth inception to March 2021. The statistical analyses were conducted using OpenMeta-Analyst software. All 11 included studies were considered for the metaanalysis. The included studies focused on malaria infections, Schistosoma haematobium, Schistosoma mansoni, soil-transmitted helminths, and trichuris trichiura. The pooled summary of sensitivity and specificity estimates were moderate compared to the gold reference standard. The overall pooled estimates of sensitivity, specificity, positive likelihood ratio, negative likelihood ratio and diagnostic odds ratio of mobile-linked POC diagnostic devices were as follows: 0.499 (95\% CI: 0.458-0.541); 0.535 (95\% CI: 0.401-0.663); 0.952 (95\% CI: 0.60 1.324); 1.381 (95\% CI: 0.391-4.879); and 0.944 (95\% CI: 0.579-1.538), respectively. Evidence shows that mobile-linked POC diagnostics' diagnostic accuracy is presently moderate in detecting infections in sub-Saharan Africa. Future research is recommended to evaluate mHealth devices' diagnostics with excellent sensitivities and specificities in diagnosing diseases in this setting.
\end{abstract}

Prospero registration: CRD 42020155041

Keywords: mHealth devices; diagnosis; accuracy; sensitivity; specificity; sub-Saharan Africa 


\section{Introduction}

Currently, sub-Saharan Africa (SSA) bears the highest disease burden worldwide (13). The high rate of infectious diseases, high recurrence of epidemics, increasing growth of chronic diseases, weak healthcare systems, insufficient funds to support healthcare, inadequately skilled health professionals, and poor healthcare infrastructure pose a significant challenge in improving healthcare provision SSA (13-15). Most patients or people have no access or limited access to healthcare clinics and even essential healthcare services (13). With these challenges, digital health such as mobile health (mHealth) applications have demonstrated their potentials in screening and testing communicable and non-communicable diseases at point-of-care diagnostics globally, including SSA $(4,16-18)$. mHealth technology is considered one of the emerging diagnostic tools or recognized as an enabling technology for disease diagnosis (1-4). In this study, we defined mHealth as the use of mobile health devices such as smartphones, tablets, and others as diagnostic tools to diagnose or detect existing disease conditions of patients.

The current global outbreak of the novel Coronavirus infections has overstretched many healthcare systems, and its implications are still unfolding. With the considerably increasing number of cases and limited available resources, there is a growing need for deployment and scalable solutions such as digital health technologies, including mHealth applications, to monitor and manage the pandemic (3-5). A recent study in the USA shows mHealth applications' use to screen healthcare workers for COVID-19 symptoms to control this disease's spread (3). Other studies conducted in the USA, Canada, and Taiwan have also demonstrated the use mHealth applications for preliminary screening and early detection of possible COVID19 infected persons and accelerating linkage to care $(2,6,7)$.

We defined disease diagnosis as the process of identifying a health condition, disorder, or problem by a systematic analysis of a patient's background or history, examining the signs or symptoms, evaluating the research or test results, and investigating the probable causes (8). The diagnosis of disease conditions can be performed accurately or inaccurately by health professionals, patients, and any other relevant person. In this study, diagnostic accuracy can generally be defined as the authentic results that contain both true positive (sensitivity) and true negative (specificity) of a disease condition in a population (9). Diagnostic accuracy can further be described as a test's ability to discriminate between the target disease condition and health (10). Mobile health technology could be defined as using mHealth devices such as simple mobile phones, smartphones, tablets, and others to provide actual results that include sensitivity, specificity, and predictive values of a target disease condition and health situations (11).

Our scoping review aimed at mapping evidence on mHealth applications to diagnose diseases and support treatment procedures by healthcare workers in sub-Saharan Africa (12). The results showed that mHealth applications are available and utilized to support healthcare services by health professionals. The results demonstrated that mHealth applications are being used for diagnosing certain disease conditions in sub-Saharan Africa. The results further indicated that mHealth applications are being utilized to manage HIV, TB, cancer, and hypertension cases in sub-Saharan Africa (12). In recent times, mobile health devices are being used to provide accurate and rapid diagnosis of diseases at POC diagnostics, which is critical in promptly providing effective and life-saving treatments (13-16). Other studies have also demonstrated that access to a simple mHealth device at POC diagnostics can potentially transform individuals' health behavior and improve people's preventive interventions in hard-to-reach communities $(17,18)$. Similar studies revealed that $\mathrm{mHealth}$ devices had been used in resource- 
poor settings at POC diagnostics to detect recent infectious Ebola, Severe Acute Respiratory Syndrome (SARS), and Zika viruses to help in the early treatment of such cases (19-22). Although the advent of mobile-linked diagnostics at point-of-care in resource-limited settings helps improve access to healthcare and reduce healthcare inequalities $(13,14)$, there is limited evidence on their diagnostic accuracy. Therefore, we performed this systematic review and meta-analysis to evaluate mobile-linked POCdiagnostics' accuracy in sub-Saharan Africa (SSA).

\section{Materials and Methods}

The review followed the Preferred Reporting Items requirements for Systematic Reviews and Meta-Analysis (PRISMA) (23). The Population, Intervention, Comparison, and Outcome (PICO) framework for determining the primary research question eligibility (Table 1) was followed.

The primary research question was: What is the evidence on the diagnostic accuracy of mobilelinked POC diagnostics' in sub-Saharan Africa?

Table 1: PICO framework for determining the eligibility of the research question

\begin{tabular}{|l|l|}
\hline Determinants & Description \\
\hline P-Population & $\begin{array}{l}\text { Diseases such as communicable and non- } \\
\text { communicable ones }\end{array}$ \\
\hline I-Intervention & Type of mobile-linked POC diagnostics \\
\hline C-Comparison & Other forms of diagnostic devices \\
\hline O-Outcome & $\begin{array}{l}\text { Diagnostic accuracy is defined as the actual } \\
\text { results that contain both true positive } \\
\text { (sensitivity) and true negative (specificity) of } \\
\text { a disease condition in a population (24). }\end{array}$ \\
\hline
\end{tabular}

\subsection{Search strategy}

An electronic search was carried out to identify all relevant published descriptive quantitative studies, randomized controlled trials, non-randomized controlled trials, and mixed-method studies to answer the review question. The search strategy included all relevant quantitative studies published from the inception of mHealth technology to March 2021 to show the patterns of reports on the diagnostic accuracy of mobile-linked POC diagnostics in sub-Saharan Africa. As part of our search criteria, database searches were conducted from mHealth technology inception to July 2019. They were updated in March 2021 using PubMed, Science Direct, Google Scholar, MEDLINE, and CINAHL with full text via EBSCOhost databases. Reference lists of all included studies eligible for inclusion were also searched for relevant potential articles. Boolean terms (AND, OR) and MeSH (Medical Subject Headings) terms which formed part of the search strategy, were used. The keywords used for the search included: "mHealth technologies", "mHealth apps", "mHealth devices", "point of care diagnostics", "diagnostic", "accuracy", "sensitivity", "specificity", "health workers" and "sub-Saharan Africa" (Additional file 1). Limitations such as date and language during the search were removed to capture all the necessary literature on mobile-linked POC diagnostics' diagnostic accuracy in SSA. 


\subsection{Study selection}

Following databases search for all the relevant studies, the principal investigator (EO) initially screened all titles of articles identified via the search strategy. All the eligible study titles were then exported to an Endnote X9 library specifically designed for this review. All duplicates identified were deleted, and the Endnote library was shared with the review team for abstract screening, which EO and PNV performed in parallel. All discrepancies between the reviewer's results following abstract screening were resolved through discussion until consensus was reached. Included studies following abstract screening were included in full article screening, which was performed by two reviewers EO and PNV, independently in parallel. TPM-T, a third reviewer, was invited to resolve all the discrepancies in screeners' results following the fulltext screening. The screening was guided by the eligibility criteria presented below:

\subsection{Eligibility criteria}

To ensure that all relevant evidence sources were identified and selected for our review, the study selection process was guided by the eligibility criteria specified under the inclusion and exclusion criteria. The origins of evidence included information from published primary studies that reported mobile-linked POC diagnostics' diagnostic accuracy.

\subsubsection{Inclusion criteria}

The following criteria were used:

- Articles that presented evidence on Health Professionals using mHealth devices at POC diagnostics.

- Articles that presented evidence on diseases diagnosed at POC diagnostics.

- Articles that reported evidence on mHealth devices such as smartphones, tablets, and others for POC diagnostics.

- Studies that published evidence on other diagnostic tools linked to POC diagnostics.

- Studies reported mHealth interventions such as voice calls, text messages, mobile apps, and multimedia messaging.

- Articles published on the diagnostic accuracy of mobile-linked POC diagnostics.

- Articles that presented evidence from sub-Saharan Africa.

\subsubsection{Exclusion criteria}

The following were excluded:

- Studies that presented evidence of patients using mHealth devices at POC diagnostics.

- Studies reported evidence on using mHealth devices for diagnosing injuries such as burns, cuts, and others.

- Articles that reported evidence on typical diagnostic devices.

- Articles published on mHealth devices support treatment in appointment reminders, medication and treatment compliance, and others. 
- Studies that showed evidence on mHealth for disease surveillance.

- Articles that showed evidence on mHealth for medical education.

- Studies published evidence on using mHealth for communication purposes.

- Articles that published evidence outside sub-Saharan Africa

\subsection{Data Extraction}

We designed a data extraction tool specifically for this review to extract all the relevant data from the included primary studies. The data for the analysis extracted from the included primary studies were in two sections: basic information and the primary study outcomes. The first section had the name of the author(s), date of publication, the aim of the study, country of research, study design, geographical settings, study setting, study population, sample size, type of mobile-linked POC diagnostics, nature of mHealth intervention, key findings, most significant outcomes of the study and conclusions. The second section also included true positive values, false-positive values, true negative values, false negative values, sensitivity, specificity from each of the included primary studies, and a 2 × 2 table was constructed. EO and TPM-T independently conducted the included studies' data extraction using the designed standard data extraction tool. A discussion resolved discrepancies between the reviewers' responses until a consensus was reached.

\subsection{Assessment of methodological quality}

Quality Assessment of Diagnostic Accuracy Studies 2 (QUADAS-2) tool was employed to assess the quality of all the included primary studies (25). Quadas-2 is a well-structured tool recommended by the Cochrane Collaboration for determining diagnostic accuracy studies by evaluating them under four main domains: patient selection, index test, reference standard, and flow and timing (25). The included primary studies' risk of bias was comprehensively assessed independently by two reviewers (EO and TPM-T). All the disagreements in their assessment were resolved via a discussion.

\subsection{Data Analysis}

The meta-analysis of diagnostic accuracy was considered for studies whose sensitivity and specificity had been evaluated. Statistical analyses were all performed using the R-based software Open Meta-Analyst (26). A random-effects model (DerSimonian-Laird) was used to calculate the pooled sensitivity, specificity, and diagnostic odds ratio (DOR) with a 95\% confidence interval $(\mathrm{CI})$. A summary receiver operating characteristic curve (ROC) was constructed by plotting the individual and summary points of sensitivity and specificity to determine mobile devices' overall diagnostic accuracy. Heterogeneity among the included primary studies was determined using $\mathrm{I}^{2}$ statistics where a score of $25 \%$ indicates low, a score of $50 \%$ represents moderate, and a score of $75 \%$ means high levels of heterogeneity (27). A pvalue of $<0.05$ was employed to demonstrate a statistically significant association in all the analyses. 


\section{Results}

\subsection{Search}

A total of 29,976 articles were identified from the combined search. Seven hundred and fortyeight articles were eligible from the database search. One hundred and eight-six duplicates were removed, leaving behind five hundred and sixty-two articles suitable for abstract screening. A total of four hundred and ninety-nine articles were excluded following the abstract screening. Sixty-three articles were eligible for full-text screening. Fifty-two of them were excluded, as illustrated in Figure 1, showing the PRISMA flow chart of literature search and selection of studies. Finally, eleven articles were included for data extraction, which further underwent quantitative meta-analysis. 


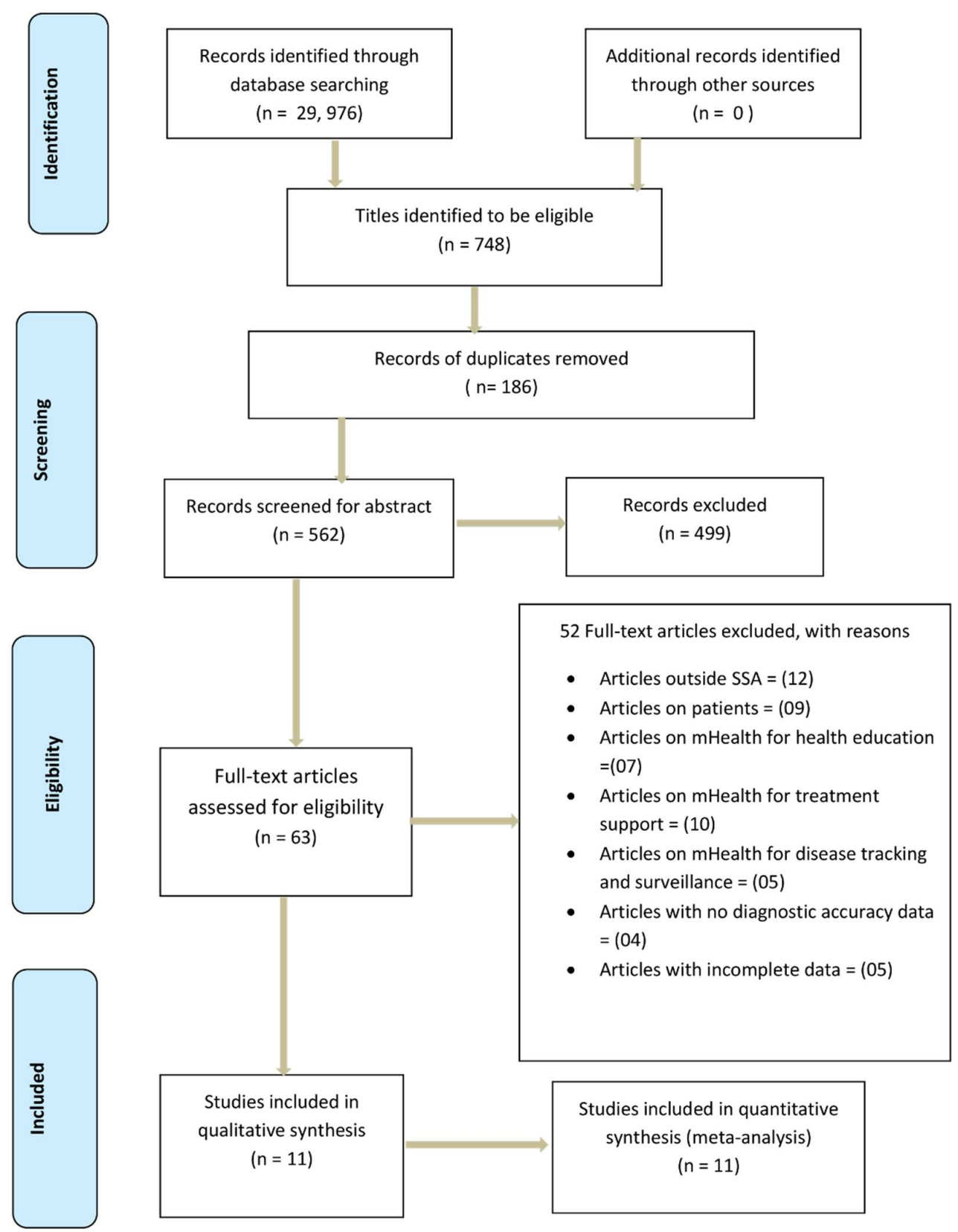

Figure 1: PRISMA flow chart showing literature search and selection of studies

\subsection{Characteristics of the Included articles}

Table 2 illustrates the characteristics of the included studies. A total of eleven articles were reviewed, and all underwent meta-analysis. Three of the included articles were conducted in Côte d'Ivoire (28-30), two in Ghana $(31,32)$, two in Uganda $(33,34)$, two in Sudan $(35,36)$, one in Tanzania (37), and one in Ethiopia (38). Sample sizes ranged from 50-1530 persons. Out of eleven studies, only one employed cohort study (30) and ten used cross-sectional studies (28, 29, 31-38), and one cohort study (30). All the included primary studies presented findings on the diagnostic accuracy of mobile-linked POC diagnostics in SSA. In terms of geographical settings, eight of the included studies were conducted in rural locations $(28-32,37,38)$, whiles three were conducted in urban settings $(33,35,36)$. All the 11 included studies were conducted in English language from 2010-2017. All the 11 included studies reported on only the diagnostic accuracy of mobile-linked POC diagnostic devices. 
Table 2: Characteristics of the included studies

\begin{tabular}{|c|c|c|c|c|c|c|c|c|c|}
\hline $\begin{array}{l}\text { Author } \\
\text { and date }\end{array}$ & $\begin{array}{l}\text { Country of } \\
\text { study }\end{array}$ & Aim of the study & $\begin{array}{l}\text { Geographical } \\
\text { setting } \\
\text { (urban/semi- } \\
\text { urban/rural) }\end{array}$ & $\begin{array}{l}\text { Study } \\
\text { setting }\end{array}$ & Study design & $\begin{array}{l}\text { Study } \\
\text { population } \\
\text { (diseases) }\end{array}$ & $\begin{array}{l}\text { Type of } \\
\text { mHealth } \\
\text { devices }\end{array}$ & $\begin{array}{l}\text { Other } \\
\text { diagnostic } \\
\text { devices (Gold } \\
\text { standard) }\end{array}$ & Sample size \\
\hline $\begin{array}{l}\text { Coulibaly } \\
\text { et al., } \\
\text { 2016a (29) }\end{array}$ & Côte d'Ivoire & $\begin{array}{l}\text { To compare the } \\
\text { accuracy of mobile } \\
\text { phone and handheld } \\
\text { devices to light } \\
\text { microscopy to } \\
\text { diagnose Schistosoma } \\
\text { haematobium, S. } \\
\text { mansoni, and intestinal } \\
\text { protozoa infections in } \\
\text { a community-based } \\
\text { survey }\end{array}$ & Rural & $\begin{array}{l}\text { Grand } \\
\text { Moutcho } \\
\text { community }\end{array}$ & $\begin{array}{l}\text { Cross- } \\
\text { sectional } \\
\text { survey }\end{array}$ & $\begin{array}{l}\text { Schistosoma } \\
\text { haematobium } \\
\text { Schistosoma } \\
\text { mansoni, } \\
\text { and } \\
\text { Intestinal } \\
\text { Protozoa } \\
\text { Infections }\end{array}$ & $\begin{array}{l}\text { Newton Nm1 } \\
\text { reversed } \\
\text { lens } \\
\text { CellScope }\end{array}$ & $\begin{array}{l}\text { Olympus CX21 } \\
\text { microscope }\end{array}$ & 226 \\
\hline $\begin{array}{l}\text { Coulibaly } \\
\text { et al., } \\
2016 b \text { (39) }\end{array}$ & Côte d'Ivoire & $\begin{array}{l}\text { To evaluate the "real- } \\
\text { world" diagnostic } \\
\text { operating } \\
\text { characteristics of a } \\
\text { handheld light } \\
\text { microscope with } \\
\text { mobile phone } \\
\text { attachment integrated } \\
\text { into a community- } \\
\text { based screening } \\
\text { program for malaria in } \\
\text { rural Côte d'Ivoire }\end{array}$ & Rural & $\begin{array}{l}\text { Grand } \\
\text { Moutcho } \\
\text { community }\end{array}$ & $\begin{array}{l}\text { Cross- } \\
\text { sectional } \\
\text { survey }\end{array}$ & $\begin{array}{l}\text { Malaria } \\
\text { (Plasmodium } \\
\text { falciparum) }\end{array}$ & Newton Nm1 & $\begin{array}{l}\text { Olympus CX22 } \\
\text { microscope }\end{array}$ & 223 \\
\hline $\begin{array}{l}\text { Bogoch et } \\
\text { al., } 2014 \\
(30)\end{array}$ & Côte d'Ivoire & $\begin{array}{l}\text { To examine the utility } \\
\text { of a novel commercial, } \\
\text { portable light } \\
\text { microscope and a } \\
\text { simple mobile phone } \\
\text { microscope to }\end{array}$ & Rural & $\begin{array}{l}\text { Azaguié } \\
\text { Makouguié }\end{array}$ & Cohort study & $\begin{array}{l}\text { Schistosoma } \\
\text { mansoni, } \\
\text { Schistosoma } \\
\text { haematobium } \\
\&\end{array}$ & $\begin{array}{l}\text { iPhone add- } \\
\text { on, Newton } \\
\text { Nm1 }\end{array}$ & $\begin{array}{l}\text { Olympus CX21 } \\
\text { microscope }\end{array}$ & 180 \\
\hline
\end{tabular}




\begin{tabular}{|c|c|c|c|c|c|c|c|c|c|}
\hline & & $\begin{array}{l}\text { diagnose S. mansoni, S. } \\
\text { haematobium, and } \\
\text { soil-transmitted } \\
\text { helminths. }\end{array}$ & & & & $\begin{array}{l}\text { Soil- } \\
\text { transmitted } \\
\text { helminths }\end{array}$ & & & \\
\hline $\begin{array}{l}\text { Bogoch et } \\
\text { al., } 2017 \\
\text { (32) }\end{array}$ & Ghana & $\begin{array}{l}\text { To test the } \\
\text { performance of the } \\
\text { handheld microscope } \\
\text { in the diagnosis of } \\
\text { Schistosoma. }\end{array}$ & Rural & $\begin{array}{l}\text { Sorodofo- } \\
\text { Abaasa Village }\end{array}$ & $\begin{array}{l}\text { Cross- } \\
\text { sectional } \\
\text { survey }\end{array}$ & $\begin{array}{l}\text { Schistosoma } \\
\text { haematobium }\end{array}$ & $\begin{array}{l}\text { Novel } \\
\text { Mobile } \\
\text { phone } \\
\text { microscope }\end{array}$ & $\begin{array}{l}\text { Olympus CX21 } \\
\text { microscope }\end{array}$ & 60 \\
\hline $\begin{array}{l}\text { Sousa- } \\
\text { Figueiredo } \\
\text { et al., } 2010 \\
\text { (34) }\end{array}$ & Uganda & $\begin{array}{l}\text { To assess the } \\
\text { diagnostic } \\
\text { performance of } \\
\text { the CyScope and the } \\
\text { lateral-flow Paracheck- } \\
\text { Pf } \\
\text { test as RDTs for } \\
\text { malaria in children } \\
\text { under five and women }\end{array}$ & Rural & $\begin{array}{l}\text { Bugoigo, } \\
\text { Walukuba, } \\
\text { Piida, } \\
\text { Bugoto, } \\
\text { Bukoba, } \\
\text { Lwanika }\end{array}$ & $\begin{array}{l}\text { Cross- } \\
\text { sectional } \\
\text { survey }\end{array}$ & $\begin{array}{l}\text { Malaria } \\
\text { (Plasmodium } \\
\text { spp) }\end{array}$ & CyScope & $\begin{array}{l}\text { Thick Giemsa } \\
\text { Smear }\end{array}$ & 1530 \\
\hline $\begin{array}{l}\text { Bogoch et } \\
\text { al., } 2013 \\
\text { (37) }\end{array}$ & Tanzania & $\begin{array}{l}\text { To compare the } \\
\text { diagnostic accuracy of } \\
\text { our mobile } \\
\text { phone microscope with } \\
\text { conventional light } \\
\text { microscopy }\end{array}$ & Rural & $\begin{array}{l}\text { Pemba } \\
\text { Island }\end{array}$ & $\begin{array}{l}\text { Cross- } \\
\text { sectional } \\
\text { survey }\end{array}$ & $\begin{array}{l}\text { Trichuris } \\
\text { trichiura }\end{array}$ & $\begin{array}{l}\text { iPhone add- } \\
\text { on }\end{array}$ & $\begin{array}{l}\text { Olympus CX21 } \\
\text { microscope }\end{array}$ & 199 \\
\hline $\begin{array}{l}\text { Stothard } \\
\text { et al., } 2014 \\
\text { (33) }\end{array}$ & Uganda & $\begin{array}{l}\text { To assess the } \\
\text { diagnostic } \\
\text { performance of } \\
\text { Newton Nm1 } \\
\text { microscope towards } \\
\text { malaria microscopy }\end{array}$ & Urban & Kampala & $\begin{array}{l}\text { Cross- } \\
\text { sectional } \\
\text { study }\end{array}$ & $\begin{array}{l}\text { Malaria } \\
\text { (Plasmodium } \\
\text { spp) }\end{array}$ & $\begin{array}{l}\text { Newton } \\
\mathrm{Nm} 1\end{array}$ & $\begin{array}{l}\text { Olympus CX22 } \\
\text { microscope }\end{array}$ & 50 \\
\hline $\begin{array}{l}\text { Birhanie et } \\
\text { al., } 2015 \\
\text { (38) }\end{array}$ & Ethiopia & $\begin{array}{l}\text { To assess the } \\
\text { diagnostic } \\
\text { performance of } \\
\text { Partec rapid malaria } \\
\text { test regarding light } \\
\text { microscopy for the }\end{array}$ & Rural & $\begin{array}{l}\text { Gendewuha } \\
\text { health } \\
\text { center }\end{array}$ & $\begin{array}{l}\text { Cross- } \\
\text { sectional } \\
\text { study }\end{array}$ & $\begin{array}{l}\text { Malaria } \\
\text { (Plasmodium } \\
\text { spp) }\end{array}$ & CyScope & $\begin{array}{l}\text { Thick Giemsa } \\
\text { Smear }\end{array}$ & 180 \\
\hline
\end{tabular}




\begin{tabular}{|c|c|c|c|c|c|c|c|c|c|}
\hline & & $\begin{array}{l}\text { diagnosis of malaria in } \\
\text { Northwest Ethiopia }\end{array}$ & & & & & & & \\
\hline $\begin{array}{l}\text { Hassan et } \\
\text { al., } 2010 \\
\text { (36) }\end{array}$ & Sudan & $\begin{array}{l}\text { To examine the } \\
\text { specificity and } \\
\text { sensitivity of } \\
\text { CyScope microscope in } \\
\text { compared to the gold } \\
\text { standard of } \\
\text { light microscopy }\end{array}$ & Urban & $\begin{array}{l}\text { Sinnar } \\
\text { hospital }\end{array}$ & $\begin{array}{l}\text { Cross- } \\
\text { sectional } \\
\text { study }\end{array}$ & $\begin{array}{l}\text { Malaria } \\
\text { (Plasmodium } \\
\text { falciparum) }\end{array}$ & CyScope & $\begin{array}{l}\text { Thick Giemsa } \\
\text { Smear }\end{array}$ & 293 \\
\hline $\begin{array}{l}\text { Hassan et } \\
\text { al., } 2011 \\
\text { (35) }\end{array}$ & Sudan & $\begin{array}{l}\text { To compare the } \\
\text { performance of } \\
\text { CyScope } \\
\text { fluorescence } \\
\text { microscope with the } \\
\text { Giemsa-stained light } \\
\text { microscopy for the } \\
\text { diagnosis of malaria } \\
\text { among pregnant } \\
\text { women }\end{array}$ & Urban & $\begin{array}{l}\text { Medani } \\
\text { Maternity } \\
\text { hospital }\end{array}$ & $\begin{array}{l}\text { Cross- } \\
\text { sectional } \\
\text { study }\end{array}$ & $\begin{array}{l}\text { Malaria } \\
\text { (Plasmodium } \\
\text { falciparum) }\end{array}$ & CyScope & $\begin{array}{l}\text { Thick Giemsa } \\
\text { Smear }\end{array}$ & 128 \\
\hline $\begin{array}{l}\text { Nkrumah } \\
\text { et al., } 2011 \\
\text { (31) }\end{array}$ & Ghana & $\begin{array}{l}\text { To compare two the } \\
\text { novel Partec Rapid } \\
\text { Malaria Test and the } \\
\text { Binax Now Malaria } \\
\text { Rapid Diagnostic Test } \\
\text { with the conventional } \\
\text { Giemsa stain } \\
\text { microscopy for } \\
\text { malaria diagnosis in } \\
\text { children at the clinical } \\
\text { laboratory of a health } \\
\text { facility in a rural } \\
\text { endemic area of Ghana }\end{array}$ & Rural & $\begin{array}{l}\text { Agogo } \\
\text { Presbyterian } \\
\text { hospital }\end{array}$ & $\begin{array}{l}\text { Cross- } \\
\text { sectional } \\
\text { survey }\end{array}$ & $\begin{array}{l}\text { Malaria } \\
\text { (Plasmodium } \\
\text { falciparum) }\end{array}$ & CyScope & $\begin{array}{l}\text { Thick Giemsa } \\
\text { Smear }\end{array}$ & 263 \\
\hline
\end{tabular}




\subsection{Assessment of risk and applicability}

Table 3 shows the risk of bias and applicability concern assessment of the included studies using the QUADAS-2 tool. The results illustrate a range of findings in the included studies that employed QUADAS-2 as the quality assessment tool (25). Participants' enrolment in all the included studies was not a random sampling technique regarding the patient selection domain but rather a convenience approach. Even though it is highly possible that the convenience sampling technique could introduce a high-risk bias, it is unlikely to affect the diagnostic accuracy of mHealth devices. The reference standard domain was found to be at low risk of bias across all the included studies. This may contribute to the diagnostic accuracy of mHealth devices for the detection of diseases. All the included studies were at low risk of bias in the flow and timing domain. However, all the studies included were at high risk of bias under the patient selection. Concerning the applicability assessment, nine of the included studies were at low risk of bias $(39-41,43-45,47,48)$, while two were found to be a high risk of bias $(31,35)$. Figure 2 displays the graphical results of the included studies from the QUADAS-2 assessment tool.

Table 3: Summary of methodological quality assessed with the QUADAS-2

\begin{tabular}{|c|c|c|c|c|c|c|c|}
\hline \multicolumn{5}{|c|}{ RISK OF BIAS } & \multicolumn{3}{|c|}{ APPLICABILITY CONCERNS } \\
\hline $\begin{array}{l}\text { Author and } \\
\text { year of } \\
\text { publication }\end{array}$ & $\begin{array}{l}\text { PATIENT } \\
\text { SELECTION }\end{array}$ & \begin{tabular}{|l|} 
INDEXX \\
TEST
\end{tabular} & $\begin{array}{l}\text { REFERENCE } \\
\text { STANDARD }\end{array}$ & $\begin{array}{l}\text { FLOW } \\
\text { AND } \\
\text { TIMING }\end{array}$ & $\begin{array}{l}\text { PATIENT } \\
\text { SELECTION }\end{array}$ & $\begin{array}{l}\text { INDEX } \\
\text { TEST }\end{array}$ & $\begin{array}{l}\text { REFERENCE } \\
\text { STANDARD }\end{array}$ \\
\hline $\begin{array}{l}\text { Bogoch et } \\
\text { al., } 2014\end{array}$ & $\because$ & $\because$ & (:) & (:) & (:) & ;) & (:) \\
\hline $\begin{array}{l}\text { Coulibaly et } \\
\text { al., 2016a }\end{array}$ & $\because$ & $\because$ & (ं) & (:) & (ं) & ;) & (:) \\
\hline $\begin{array}{l}\text { Coulibaly et } \\
\text { al., } 2016 b\end{array}$ & $\because$ & $\because$ & (:) & (:) & (:) & ;) & (:) \\
\hline $\begin{array}{l}\text { Bogoch et } \\
\text { al., } 2017\end{array}$ & $\because$ & (:) & (ं) & (:) & (ं) & ;) & (:) \\
\hline $\begin{array}{l}\text { Stothard et } \\
\text { al., } 2014\end{array}$ & $\because$ & (;) & (;) & (:) & (;) & (;) & (:) \\
\hline $\begin{array}{l}\text { Bogoch et } \\
\text { al., } 2013\end{array}$ & $\because$ & (:) & (;) & (:) & (;) & (;) & (:) \\
\hline $\begin{array}{l}\text { Sousa- } \\
\text { Figueiredo } \\
\text { et al., } 2010\end{array}$ & 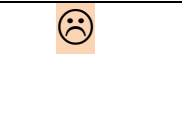 & (;) & $\odot$ & $\odot$ & (;) & (;) & (;) \\
\hline $\begin{array}{l}\text { Birhanie et } \\
\text { al., } 2015\end{array}$ & 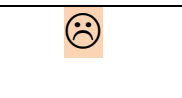 & (:) & (:) & (:) & (:) & (;) & (:) \\
\hline $\begin{array}{l}\text { Hassan et } \\
\text { al., } 2010\end{array}$ & $\ddot{\theta}$ & (:) & (:) & (:) & (:) & (:) & (:) \\
\hline $\begin{array}{l}\text { Hassan et } \\
\text { al., } 2011\end{array}$ & 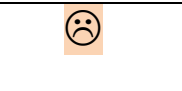 & (:) & (:) & $\odot$ & (:) & (;) & : \\
\hline
\end{tabular}




\begin{tabular}{|c|c|c|c|c|c|c|c|}
\hline $\begin{array}{l}\text { Nkrumah et } \\
\text { al., } 2011\end{array}$ & 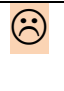 & (;) & (;) & (;) & (:) & (;) & 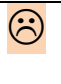 \\
\hline
\end{tabular}
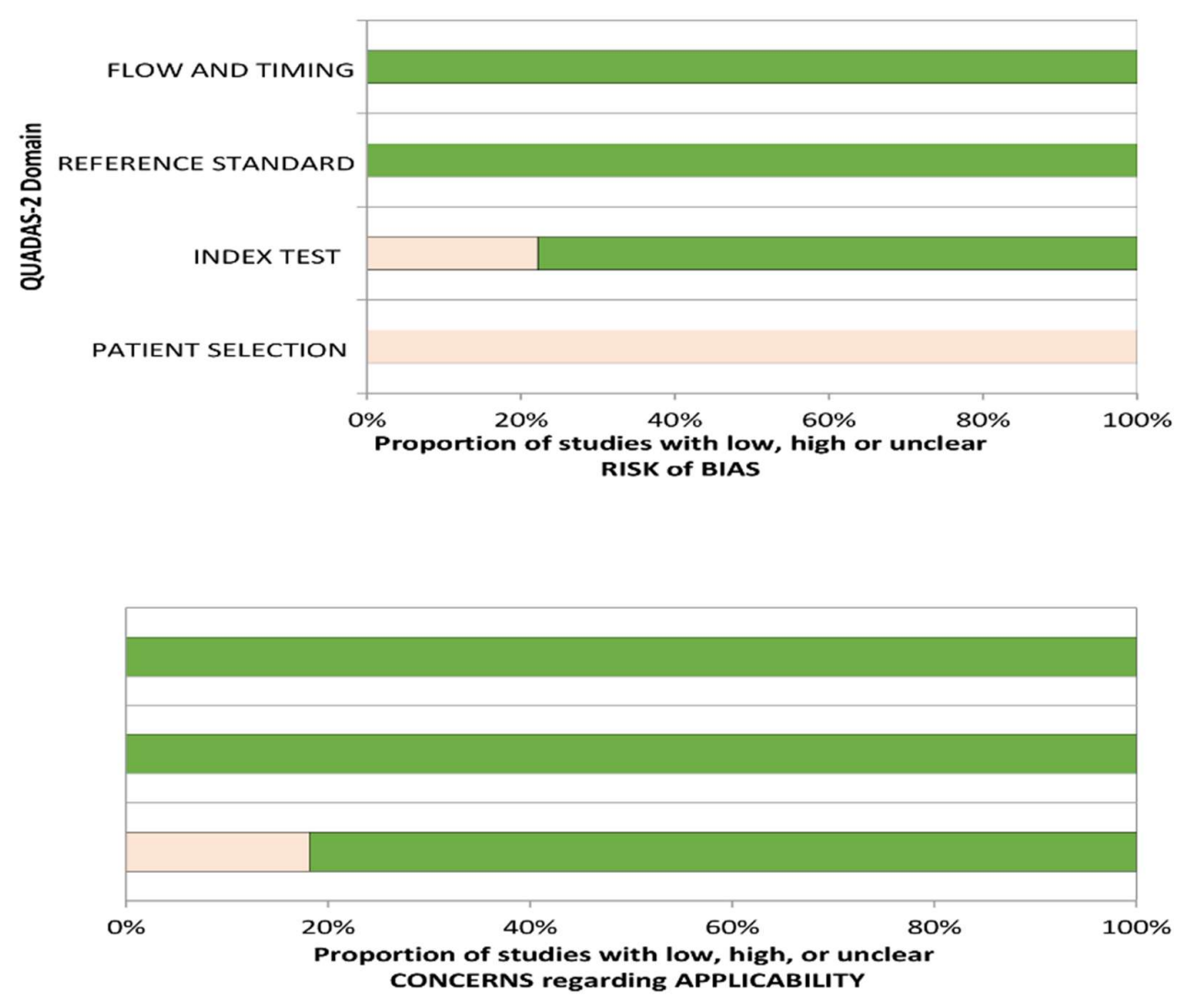

Figure 2: QUADAS-2 assessments of included studies

\subsection{Diagnostic accuracy of mobile-linked diagnostic devices}

Table 4 illustrates true-positive, false-negative, false-positive, true-negative results and their corresponding sensitivity and specificity values for mobile-linked POC diagnostic devices for detecting disease conditions. The summary estimates of sensitivity and specificity of mobilelinked devices were 0.499 (95\% CI: 0.458-0.541) and 0.535 (95\%CI: $0.401-0.663)$, respectively (Figure 3 ). The pooled estimates of specificity and sensitivity are statistically significant at the meta-analysis. The individual pooled and summary estimates of sensitivity and specificity at the $95 \%$ CI region for all the included studies of mobile-linked POC diagnostic devices are presented in an ROC graph (Figure 4). The overall pooled estimates of the positive likelihood ratio (PLR) and negative likelihood ratio (NLR) were $0.952(95 \% \mathrm{CI}$ : $0.60-1.324)$ and 1.381 (95\%CI: 0.391-4.879), respectively (Figure 5). Heterogeneity was determined as statistically insignificant as $\mathrm{I}^{2}=35.6 \%(\mathrm{p}=0.098)$ for the degree of inconsistency. The ROC curve analysis demonstrated a significantly moderate diagnostic performance of the mobile-linked POC diagnostic devices. The diagnostic odds ratio (DOR) for mobile-linked POC diagnostic devices' accuracy was found to be $\mathrm{OR}=0.944(95 \% \mathrm{CI}$ : 
0.579-1.538) (Figure 6). Hence, the overall effect estimate of the study at the meta-analysis is statistically insignificant.

Table 4: Diagnostic accuracy of mobile-linked POC diagnostic devices

\begin{tabular}{|c|c|c|c|c|c|c|c|c|c|}
\hline \multicolumn{10}{|c|}{ Mobile phone microscope/ CyScope } \\
\hline $\begin{array}{l}\text { Author, } \\
\text { date }\end{array}$ & Disease & $\begin{array}{l}\text { Sensitivity } \\
(95 \% \mathrm{Cl})\end{array}$ & $\begin{array}{l}\text { Specificity } \\
(95 \% \mathrm{Cl})\end{array}$ & $\begin{array}{l}\text { PPV } \\
(95 \% \\
\mathrm{CI}) \\
\end{array}$ & $\begin{array}{l}\text { NPV } \\
(95 \% \\
\mathrm{CI}) \\
\end{array}$ & $\begin{array}{l}\text { TP } \\
(95 \% \\
\mathrm{Cl}) \\
\end{array}$ & $\begin{array}{l}\text { FP } \\
(95 \% \\
\text { CI) } \\
\end{array}$ & $\begin{array}{l}\text { TN } \\
(95 \% \\
\text { CI) }\end{array}$ & $\begin{array}{l}\text { FN } \\
(95 \% \\
\text { Cl) } \\
\end{array}$ \\
\hline \multirow[t]{2}{*}{$\begin{array}{l}\text { Coulibaly } \\
\text { et al., } \\
2016 a\end{array}$} & $\begin{array}{l}\text { Schistosoma } \\
\text { mansoni }\end{array}$ & $\begin{array}{l}50.0 \\
(25.4-74.6)\end{array}$ & $\begin{array}{l}99.5 \\
(97.0-100)\end{array}$ & $\begin{array}{l}85.7 \\
(42.0- \\
99.2) \\
\end{array}$ & $\begin{array}{l}97.3 \\
(93.9- \\
98.9) \\
\end{array}$ & 51.0 & 0.5 & 0.51 & 50 \\
\hline & $\begin{array}{l}\text { Schistosoma } \\
\text { haematobium }\end{array}$ & $\begin{array}{l}35.6 \\
(25.9-46.4)\end{array}$ & $\begin{array}{l}100 \\
(96.6-100)\end{array}$ & $\begin{array}{l}100 \\
(86.7- \\
100) \\
\end{array}$ & $\begin{array}{l}70.1 \\
(63.1- \\
76.3) \\
\end{array}$ & 66.2 & 0.0 & 0.0 & 64.4 \\
\hline \multirow[t]{2}{*}{$\begin{array}{l}\text { Bogoch et } \\
\text { al., 2014a }\end{array}$} & $\begin{array}{l}\text { Schistosoma } \\
\text { mansoni }\end{array}$ & $\begin{array}{l}68 \cdot 2(60 \cdot 1- \\
75 \cdot 5)\end{array}$ & $\begin{array}{l}64 \cdot 3 \\
(35 \cdot 1- \\
87 \cdot 2)\end{array}$ & $\begin{array}{l}95 \cdot 4 \\
(89 \cdot 5- \\
98 \cdot 5)\end{array}$ & $\begin{array}{l}15 \cdot 8 \\
(7 \cdot 5- \\
27 \cdot 9)\end{array}$ & 32.2 & 35.7 & 36.2 & 31.8 \\
\hline & $\begin{array}{l}\text { Trichuris } \\
\text { trichiura }\end{array}$ & $\begin{array}{l}30 \cdot 8(19 \cdot 9- \\
43 \cdot 4)\end{array}$ & $\begin{array}{l}71 \cdot 0 \\
(61 \cdot 1- \\
79 \cdot 6)\end{array}$ & $\begin{array}{l}40 \cdot 8 \\
(27 \cdot 0- \\
55 \cdot 8) \\
\end{array}$ & $\begin{array}{l}61 \cdot 2 \\
(51 \cdot 7- \\
70 \cdot 1) \\
\end{array}$ & 71.5 & 29.0 & 29.0 & 69.2 \\
\hline $\begin{array}{l}\text { Bogoch et } \\
\text { al., } 2013\end{array}$ & $\begin{array}{l}\text { Trichuris } \\
\text { trichiura }\end{array}$ & $\begin{array}{l}54.4(46.3- \\
62.3)\end{array}$ & $\begin{array}{l}63.4 \text { (46.9- } \\
77.4)\end{array}$ & $\begin{array}{l}85.1 \\
(76.4- \\
91.2) \\
\end{array}$ & $\begin{array}{l}26.5 \\
(18.4- \\
36.6) \\
\end{array}$ & 46.4 & 36.6 & 37.2 & 45.6 \\
\hline $\begin{array}{l}\text { Bogoch et } \\
\text { al., } 2017\end{array}$ & $\begin{array}{l}\text { Schistosoma } \\
\text { haematobium }\end{array}$ & $\begin{array}{l}72.1(56.1- \\
84.2\end{array}$ & $\begin{array}{l}100.0 \\
(75.9- \\
100.0)\end{array}$ & $\begin{array}{l}100.0 \\
(86.3- \\
100.0) \\
\end{array}$ & $\begin{array}{l}57.1 \\
(37.4- \\
75.0) \\
\end{array}$ & 28.3 & 0.0 & 0.0 & 27.9 \\
\hline $\begin{array}{l}\text { Coulibaly } \\
\text { et al., } \\
2016 b\end{array}$ & Malaria & $\begin{array}{l}80.2 \text { (73.1- } \\
85.9)\end{array}$ & $\begin{array}{l}100(92.6- \\
100.0)\end{array}$ & $\begin{array}{l}100 \\
(96.4- \\
100.0)\end{array}$ & $\begin{array}{l}65.6 \\
(54.9- \\
74.9)\end{array}$ & 20.0 & 0.0 & 0.0 & 19.8 \\
\hline $\begin{array}{l}\text { Sousa- } \\
\text { Figueiredo } \\
\text { et al., } \\
2010\end{array}$ & Malaria & $\begin{array}{l}86.7 \\
(79.3- \\
92.2)\end{array}$ & $\begin{array}{l}38.8 \\
(33.6- \\
44.1)\end{array}$ & $\begin{array}{l}32.8 \\
(27.7- \\
38.3)\end{array}$ & $\begin{array}{l}89.4 \\
(83.4- \\
93.8)\end{array}$ & 13.3 & 61.2 & 62.8 & 13.3 \\
\hline $\begin{array}{l}\text { Stothard } \\
\text { et al., } \\
2014\end{array}$ & Malaria & $\begin{array}{l}93.5 \text { (78.6- } \\
99.2)\end{array}$ & $\begin{array}{l}100(82.4- \\
100)\end{array}$ & $\begin{array}{l}100 \\
(88.1- \\
100) \\
\end{array}$ & $\begin{array}{l}90.5 \\
(69.6- \\
98.8) \\
\end{array}$ & 6.5 & 0.0 & 0.0 & 6.5 \\
\hline $\begin{array}{l}\text { Birhanie } \\
\text { et al., } \\
2015\end{array}$ & Malaria & $\begin{array}{l}93.8(87.1- \\
100)\end{array}$ & $\begin{array}{l}87.9(79.7- \\
96.1)\end{array}$ & $\begin{array}{l}86.4 \\
(77.2- \\
95.5) \\
\end{array}$ & $\begin{array}{l}94.6 \\
(88.7- \\
100) \\
\end{array}$ & 6.3 & 12.1 & 12.2 & 6.2 \\
\hline $\begin{array}{l}\text { Hassan et } \\
\text { al., } 2010\end{array}$ & Malaria & $\begin{array}{l}98.2 \text { (90.6- } \\
100)\end{array}$ & $\begin{array}{l}98.3 \text { (95.7- } \\
99.5)\end{array}$ & $\begin{array}{l}93.3 \\
(83.8- \\
98.2) \\
\end{array}$ & $\begin{array}{l}99.6 \\
(97.6- \\
100)\end{array}$ & 1.8 & 1.7 & 1.72 & 1.8 \\
\hline $\begin{array}{l}\text { Hassan et } \\
\text { al., } 2011\end{array}$ & Malaria & $\begin{array}{l}97.6(92.2- \\
99.6)\end{array}$ & $\begin{array}{l}89.1 \text { (77.5- } \\
95.9)\end{array}$ & $\begin{array}{l}94.1 \\
(87.4- \\
97.8)\end{array}$ & $\begin{array}{l}95.3 \\
(85.4- \\
99.2)\end{array}$ & 2.43 & 10.9 & 98.2 & 2.4 \\
\hline $\begin{array}{l}\text { Nkrumah } \\
\text { et al., } \\
2011 \\
\end{array}$ & Malaria & $\begin{array}{l}100(96.6- \\
100)\end{array}$ & $\begin{array}{l}97.4 \text { (93.6- } \\
99.3)\end{array}$ & $\begin{array}{l}96.4 \\
(91- \\
99) \\
\end{array}$ & $\begin{array}{l}100 \\
(97.6- \\
100) \\
\end{array}$ & 0.0 & 2.6 & 2.63 & 0.0 \\
\hline
\end{tabular}



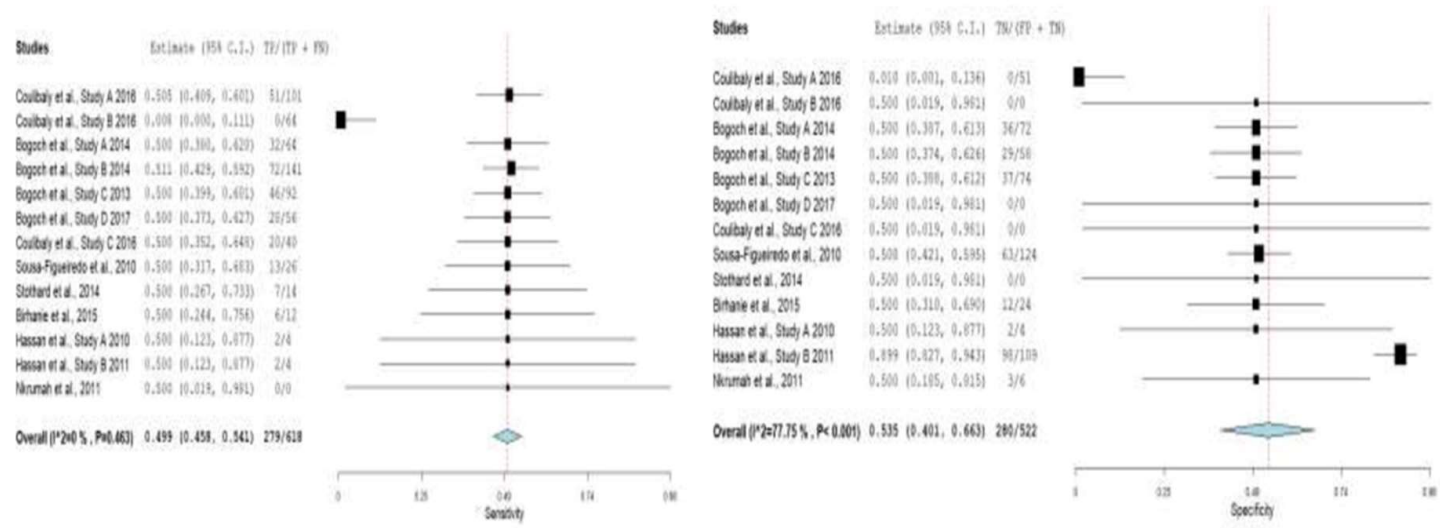

Figure 3: Forest plots of pooled sensitivity and specificity estimates for all included studies of mobile-linked diagnostic devices

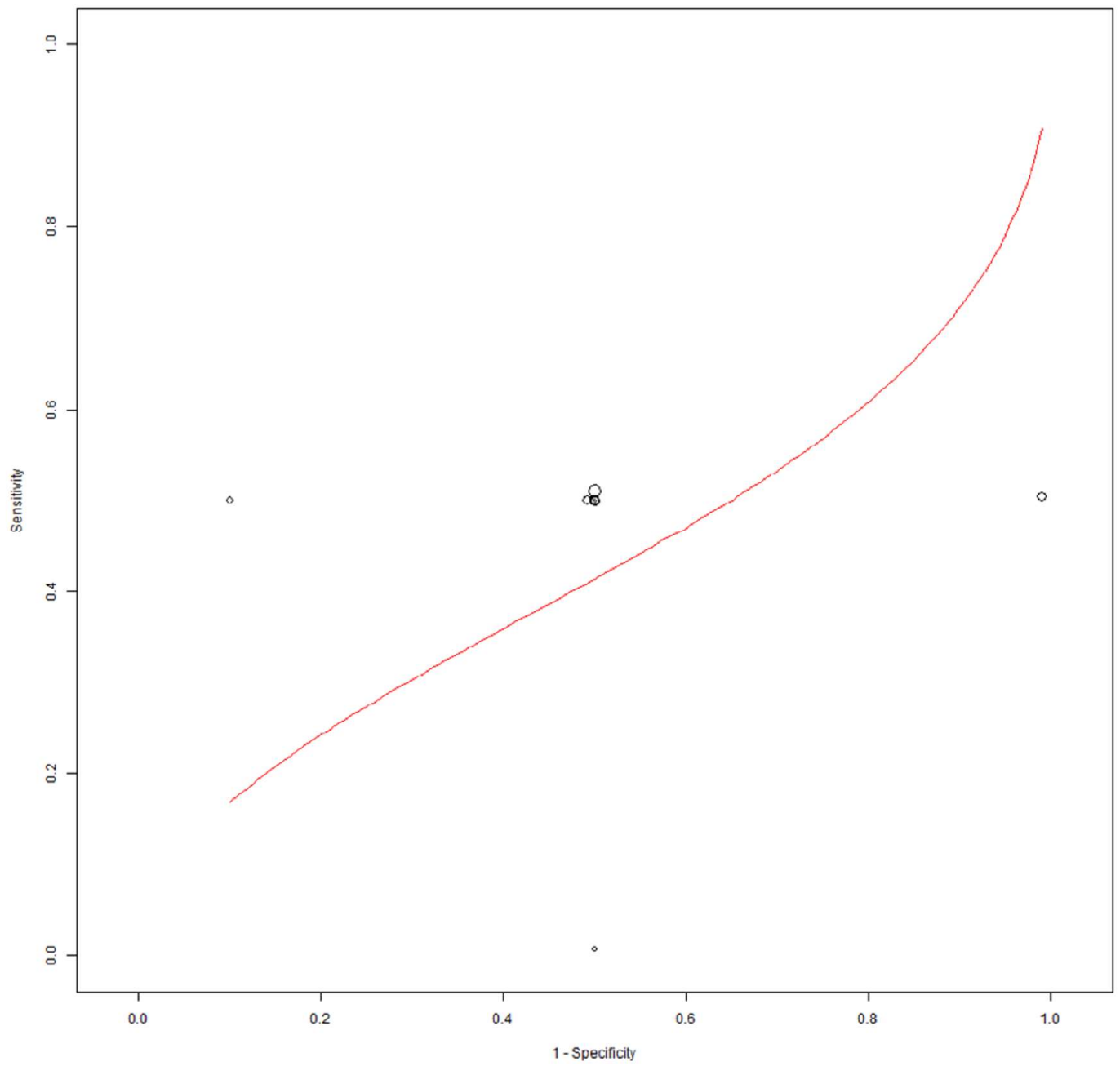

Figure 4: ROC graph of the included studies of mobile-linked POC diagnostic devices 


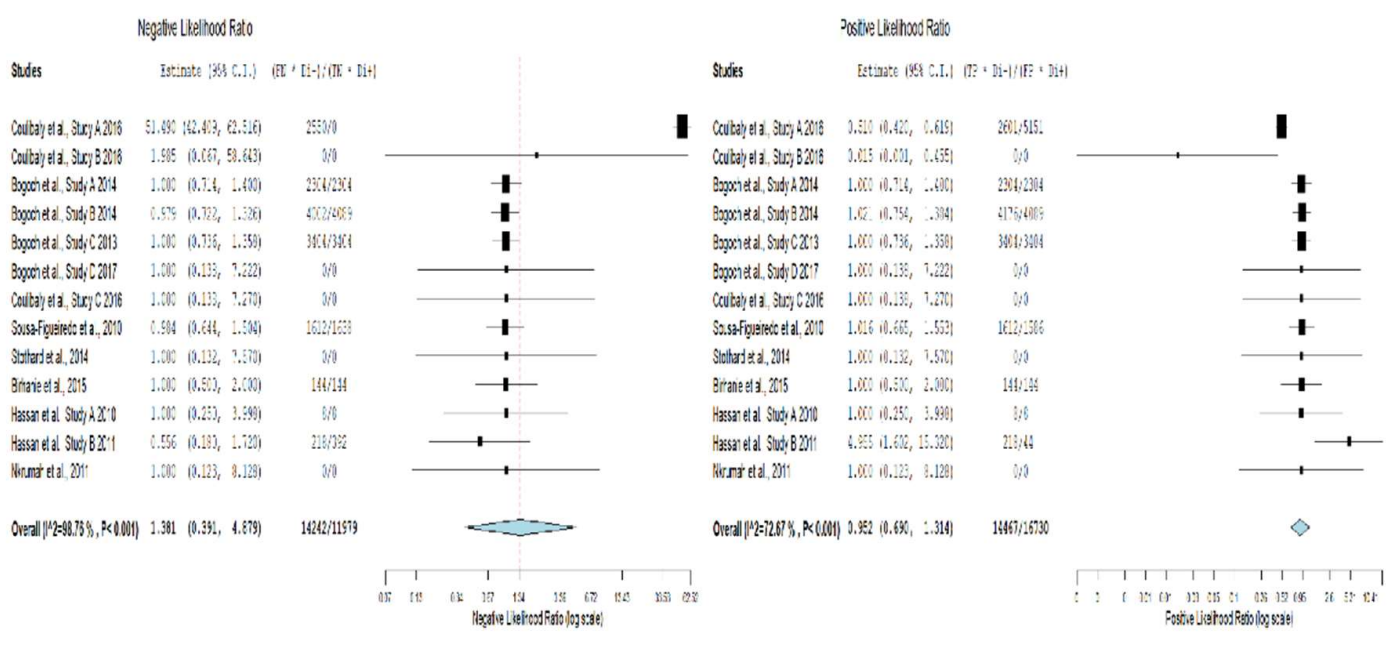

Figure 5: Negative likelihood ratio and positive likelihood ratio of the included studies of the mobile-linked POC diagnostic devices

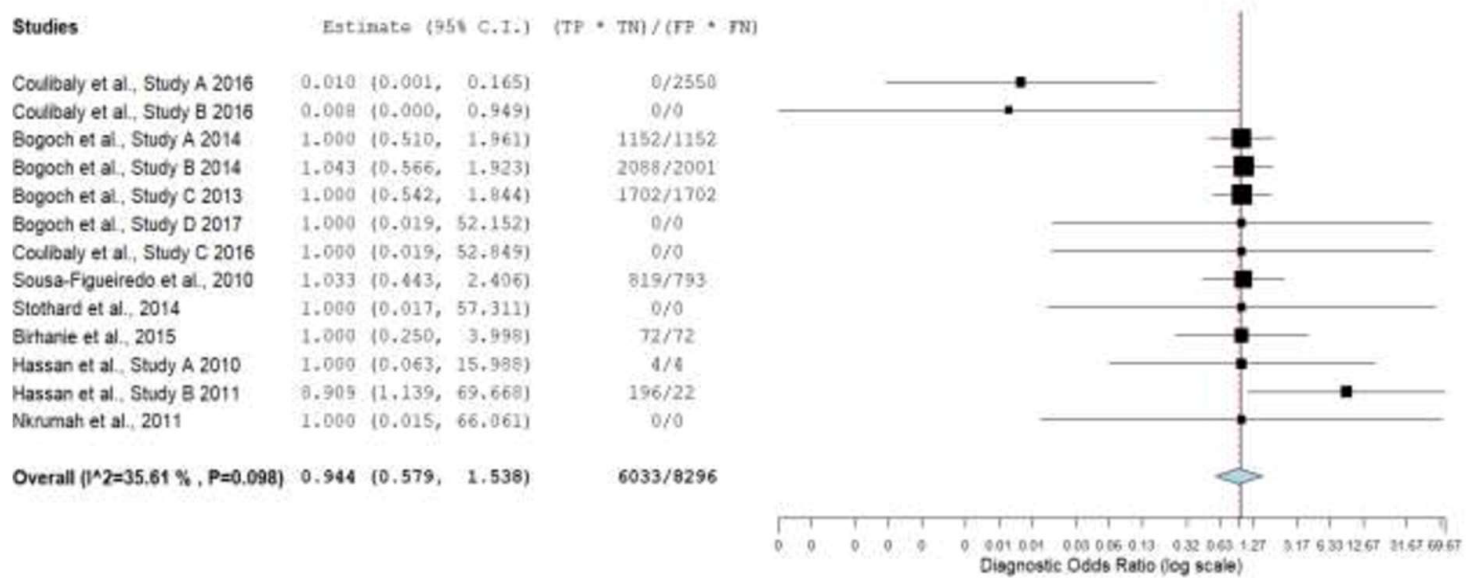

Figure 6: Diagnostic odds ratio forest plot of the included studies of mobile-linked diagnostic devices

\section{DISCUSSION}

The evidence available from this study showed a moderate diagnostic accuracy of mobilelinked POC diagnostics in sub-Saharan Africa. This systematic review's objective was to evaluate the diagnostic accuracy of mobile-linked POC diagnostics in SSA. We found that mobile-linked POC diagnostics' overall sensitivity for disease detections was $49.9 \%$, and specificity was $53.5 \%$. The meta-analysis results indicate a moderate diagnostic accuracy of mobile-linked POC diagnostic for disease detections in SSA. The ROC curve also confirms the average diagnostic performance of these mobile-linked POC diagnostic devices. This means that mobile-linked POC diagnostics have less sensitivity and specificity abilities than the cutoff value of the gold standard described by the World Health Organization (WHO) (40). We performed a sub-group analysis of the included studies to determine the rate of sensitivities and specificities of similar disease outcomes. A cursory examination of seven included studies that 
used mobile-linked POC diagnostic devices to detect malaria infections found moderate sensitivity and specificity estimates 0.500 (95\% CI: 0.352-0.648) and 0.500 (95\% CI: 0.019 0.981) compared to the cut-off value of the standard gold light microscope described as an effective diagnostic tool (40).

The results also show that two studies that used mobile-linked POC diagnostic devices to detect Schistosoma mansoni found an average sensitivity estimate of 0.500 (95\% CI: $0.380-0.620$ ) and a low specificity estimate of 0.010 (95\% CI: 0.001-0.136) compared to the gold standard conventional light microscope (40). Again, the results demonstrate that mobile-linked POC diagnostic devices for detecting Schistosoma haematobium infections found a low sensitivity estimate of 0.008 (95\% CI: 0.409-0.601) and an average specificity estimate of 0.500 (95\% CI: 0.019-0.981) compared to the gold standard conventional light microscope (40). Additionally, the results indicate that two studies that used mobile-linked POC diagnostic devices to diagnose trichuris trichiura infections found moderate sensitivity and specificity estimates of 0.511 (95\% CI: $0.429-0.592)$ and 0.500 (95\% CI: 0.388-0.612) compared to the gold standard light microscope (40). These mobile-linked POC diagnostic devices providing moderate sensitivity and specificity estimates prove that such devices are below the cut-off point compared with the gold standard light microscope that is considered an effective diagnostic tool. The moderate diagnostic abilities of mobile-linked POC diagnostic devices for infectious and non-infectious diseases could also be attributed to the first-generation mobile phone microscopes employed by most of the included studies.

A study conducted in some low-and middle-income countries found the use of mobile phone fluorescence microscopy for detecting waterborne pathogen with an accuracy of $95 \%$, which is not consistent with our study results (41). Similar studies conducted in Finland and New Zealand illustrated that mobile phone microscopes exhibited high sensitivity for detecting soiltransmitted helminths and Schistosoma, which do not agree with our study results $(42,43)$. Luis Rosado et al. carried out another study in Portugal where mobile phone microscope indicated higher sensitivity and specificity for diagnosing malaria infections at variance with this study's results (44). A survey conducted in the USA by Paul Slusarewicz et al. revealed that mobile phone microscopes detected parasite eggs in mammalian faeces with high sensitivity and specificity, which disagrees with this study's findings (45). A study conducted in Sweden revealed that mobile phone microscopes could be used extensively for clinical diagnostics when their sensitivities reach or exceed the $80 \%$ threshold (42). Studies conducted in the USA have demonstrated that mobile handheld devices had a high diagnostic accuracy at POC diagnostics for detecting coronary stenosis and other disease conditions $(16,46)$.

This review study included studies carried out in different geographical settings, giving an exhaustive overview of mobile-linked POC diagnostic devices' diagnostic accuracy in SSA. Date and language limitations were removed from this review study to capture all the essential literature on mobile-linked POC diagnostic devices' diagnostic accuracy in SSA. Nonetheless, a piece of evidence on mobile-linked POC diagnostic devices' diagnostic accuracy in SSA may have existed under different contexts that were not included in the study. This review was limited to studies that used quantitative methods since this study focused on the diagnostic accuracy of mobile-linked POC diagnostic devices in SSA. The systematic review was also limited to studies carried out in SSA and could not be made to represent the entire world.

The results illustrate that most of the studies were conducted in rural settings where there is no access or little access to standard laboratory facilities. This will benefit such rural inhabitants in improving their health conditions if these activities are often conducted in such areas. The study results provide a moderate diagnostic yield of disease conditions and may not encourage 
healthcare professionals to rely on such devices to support healthcare provision continually. This means that more technologically advanced mobile-linked POC diagnostic devices and well-validated with excellent sensitivities and specificities should be made available to these healthcare professionals and other users.

The results suggest that most of the studies that used first-generation mobile phones attached to microscopes provided a modest diagnostic yield of infectious and non-infectious diseases in resource-poor settings. We recommend future research on using low-cost technologically advanced mobile phone microscopes at POC in resource-constrained settings that may improve their diagnostic capabilities. The results also indicate that mobile-linked POC diagnostic devices' diagnostic accuracy in detecting infectious and non-infectious diseases was found only in six SSA countries. We, therefore, encourage more countries in SSA to employ these mobilelinked POC diagnostic devices to assist in diagnosing a lot more infectious and non-infectious diseases, especially in remote areas.

\section{Conclusion}

Mobile-linked POC diagnostic devices can improve healthcare provision quality in clinical and public health care to diagnose diseases in resource-constrained SSA areas. Current devices have been integrated slowly in routine clinical practice with innovations such as mobile phone microscopes, machine learning, computer vision, and others that could assist in automatic or instant diagnoses of diseases. The study results illustrate that mobile-linked POC diagnostic devices provided an average diagnostic yield in detecting infectious and non-infectious diseases in SSA. The study results further demonstrate that the first-generation mobile phones employed contributed to moderate sensitivities and specificities in diagnosing infections in low-resourced SSA settings. Hence, we recommend that a lot more primary research be carried out in SSA with mobile-linked POC diagnostic devices advanced technologically and wellvalidated to provide sensitivities and specificities estimates to reach or exceed the $80 \%$ threshold. We also recommend that more mHealth diagnostics evaluation studies use refined mHealth devices with excellent sensitivities and specificities to diagnose existing diseases in sub-Saharan Africa.

Additional file 1: Results from the initial database search

\section{Author contributions}

EO and TPM-T conceptualized and designed the study. EO, PNV, and TPM-T contributed to the abstract, full article screening, and the included studies' quality assessment. NSJ performed the meta-analysis and assisted in the interpretation of the results. EO prepared the draft of the study, TPM-T reviewed the draft critically. EO prepared the final draft, and all authors approved it.

\section{Funding statement}

This research did not receive any specific grant from funding agencies in public, commercial, or not-for-profit sectors.

\section{Institutional Review Board Statement}

Not applicable. 


\section{Informed Consent Statement}

Not applicable.

\section{Data Availability Statement}

Not applicable

\section{Competing interest statement}

The authors declare no conflict of interest.

\section{Additional information}

No additional information is available for this paper.

\section{Acknowledgments}

The authors wish to thank the University of KwaZulu-Natal for giving us all the necessary resources in developing this review.

\section{References}

1. Wood CS, Thomas MR, Budd J, Mashamba-Thompson TP, Herbst K, Pillay D, et al. Taking connected mobile-health diagnostics of infectious diseases to the field. Nature. 2019;566(7745):46774.

2. Rao ASS, Vazquez JA. Identification of COVID-19 can be quicker through artificial intelligence framework using a mobile phone-based survey in the populations when cities/towns are under quarantine. Infection Control Hospital Epidemiology. 2020:1-18.

3. Zhang H, Dimitrov D, Simpson L, Singh B, Plaks N, Penney S, et al. A Web-based, Mobile Responsive Application to Screen Healthcare Workers for COVID Symptoms: Descriptive Study. MedRxiv. 2020.

4. Alwashmi MF. The Use of Digital Health in the Detection and Management of COVID-19. International Journal of Environmental Research Public Health. 2020;17(8):2906.

5. Keesara S, Jonas A, Schulman K. Covid-19 and health care's digital revolution. New England Journal of Medicine

2020.

6. Udugama B, Kadhiresan P, Kozlowski HN, Malekjahani A, Osborne M, Li VY, et al. Diagnosing COVID-19: The Disease and Tools for Detection. ACS nano

2020.

7. Yang T, Wang Y-C, Shen C-F, Cheng C-M. Point-of-Care RNA-Based Diagnostic Device for COVID-19. Multidisciplinary Digital Publishing Institute; 2020.

8. Mallett S, Halligan S, Thompson M, Collins GSA, Douglas G Interpreting diagnostic accuracy studies for patient care. BMJ Open. 2012;345:344.

9. Warshaw EM, Lederle FA, Grill JP, Gravely AA, Bangerter AK, Fortier LA, et al. Accuracy of teledermatology for nonpigmented neoplasms. 2009;60(4):579-88.

10. Šimundić A-M. Measures of diagnostic accuracy: basic definitions. Ejifcc. 2009;19(4):203. 
11. Coppetti T, Brauchlin A, Müggler S, Attinger-Toller A, Templin C, Schönrath F, et al. Accuracy of smartphone apps for heart rate measurement. European journal of preventive cardiology. 2017;24(12):1287-93.

12. Osei E, Kuupiel D, Vezi PN, Mashamba-Thompson TP. Mapping evidence of mobile health technologies for disease diagnosis and treatment support by health workers in sub-Saharan Africa: a scoping review. J BMC Medical Informatics

Decision Making. 2021;21(1):1-18.

13. Choi S. Powering point-of-care diagnostic devices. Biotechnology advances. 2016;34(3):321-

30.

14. Rasooly R, Bruck HA, Balsam J, Prickril B, Ossandon M, Rasooly A. Improving the sensitivity and functionality of mobile webcam-based fluorescence detectors for point-of-care diagnostics in global health. Diagnostics

2016;6(2):19.

15. Xu X, Akay A, Wei H, Wang S, Pingguan-Murphy B, Erlandsson B-E, et al. Advances in smartphone-based point-of-care diagnostics. Proceedings of the IEEE

2015;103(2):236-47.

16. Berg B, Cortazar B, Tseng D, Ozkan H, Feng S, Wei Q, et al. Cellphone-based hand-held microplate reader for point-of-care testing of enzyme-linked immunosorbent assays. ACS nano

2015;9(8):7857-66.

17. Srinivasan B, O'Dell D, Finkelstein JL, Lee S, Erickson D, Mehta S. ironPhone: mobile devicecoupled point-of-care diagnostics for assessment of iron status by quantification of serum ferritin. Biosensors Bioelectronics. 2018;99:115-21.

18. Van Haelst R, editor The diagnostic accuracy of smartphone applications to detect atrial fibrillation: a head-to-head comparison between Fibricheck and AliveCor. ACTA CARDIOLOGICA; 2017: TAYLOR \& FRANCIS LTD 2-4 PARK SQUARE, MILTON PARK, ABINGDON OR14 4RN, OXON ....

19. Ahrberg CD, Manz A, Neužil P. Palm-sized device for point-of-care Ebola detection. Analytical chemistry. 2016;88(9):4803-7.

20. Song J, Mauk MG, Hackett BA, Cherry S, Bau HH, Liu C. Instrument-free point-of-care molecular detection of Zika virus. Analytical chemistry

2016;88(14):7289-94.

21. Zarei M. Portable biosensing devices for point-of-care diagnostics: Recent developments and applications. TrAC Trends in Analytical Chemistry. 2017;91:26-41.

22. Bempong N-E, De Castañeda RR, Schütte S, Bolon I, Keiser O, Escher G, et al. Precision Global Health-The case of Ebola: a scoping review. Journal of global health. 2019;9(1).

23. Moher D, Liberati A, Tetzlaff J, Altman D. Group, P., \& others.(2009). Preferred reporting items for systematic reviews and meta-analyses: the PRISMA statement. PLoS Med

6(7):e1000097.

24. Warshaw EM, Lederle FA, Grill JP, Gravely AA, Bangerter AK, Fortier LA, et al. Accuracy of teledermatology for nonpigmented neoplasms. J Am Acad Dermatol. 2009;60(4):579-88.

25. Whiting PF, Rutjes AW, Westwood ME, Mallett S, Deeks JJ, Reitsma JB, et al. QUADAS-2: a revised tool for the quality assessment of diagnostic accuracy studies. Annals of internal medicine. 2011;155(8):529-36.

26. Wallace BC, Dahabreh IJ, Trikalinos TA, Lau J, Trow P, Schmid CH. Closing the gap between methodologists and end-users: R as a computational back-end. J J Stat Softw. 2012;49(5):1-15.

27. Higgins JP, Thompson SG. Quantifying heterogeneity in a meta-analysis. J Statistics in medicine. 2002;21(11):1539-58. 
28. Coulibaly JT, Ouattara M, Keiser J, Bonfoh B, N'Goran EK, Andrews JR, et al. Evaluation of malaria diagnoses using a handheld light microscope in a community-based setting in rural Côte d'Ivoire. The American Journal of Tropical Medicine Hygiene

2016;95(4):831-4.

29. Coulibaly JT, Ouattara M, D'Ambrosio MV, Fletcher DA, Keiser J, Utzinger J, et al. Accuracy of Mobile Phone and Handheld Light Microscopy for the Diagnosis of Schistosomiasis and Intestinal Protozoa Infections in Cote d'Ivoire. PLoS NegI Trop Dis. 2016;10(6):e0004768.

30. Bogoch II, T COULIBALY J, Andrews JR, Speich B, Keiser J, Stothard JR, et al. Evaluation of portable microscopic devices for the diagnosis of Schistosoma and soil-transmitted helminth infection. Parasitology. 2014;141(14):1811.

31. Nkrumah B, Acquah SE, Ibrahim L, May J, Brattig N, Tannich E, et al. Comparative evaluation of two rapid field tests for malaria diagnosis: Partec rapid malaria test ${ }^{\circledR}$ and Binax now $^{\circledR}$ malaria rapid diagnostic test. J BMC Infectious Diseases. 2011;11(1):1-8.

32. Bogoch II, Koydemir HC, Tseng D, Ephraim RK, Duah E, Tee J, et al. Evaluation of a mobile phone-based microscope for screening of Schistosoma haematobium infection in rural Ghana. J The American journal of tropical medicine hygiene. 2017;96(6):1468-71.

33. Stothard JR, Nabatte B, Sousa-Figueiredo JC, Kabatereine NB. Towards malaria microscopy at the point-of-contact: an assessment of the diagnostic performance of the Newton Nm1 microscope in Uganda. J Parasitology. 2014;141(14):1819.

34. Sousa-Figueiredo JC, Oguttu D, Adriko M, Besigye F, Nankasi A, Arinaitwe $M$, et al. Investigating portable fluorescent microscopy $\left(\mathrm{CyScope}^{\circledR}\right)$ as an alternative rapid diagnostic test for malaria in children and women of child-bearing age. J Malaria journal. 2010;9(1):1-8.

35. Hassan SE-DH, Abd Elrahium DH, Mohammed-Elhassan EB, Malik EM, Adam I. Fluorescence microscope $\left(\right.$ Cyscope $\left.^{\circledast}\right)$ for malaria diagnosis in pregnant women in Medani Hospital, Sudan. J Diagnostic pathology. 2011;6(1):1-5.

36. Hassan SE-DH, Okoued SI, Mudathir MA, Malik EM. Testing the sensitivity and specificity of the fluorescence microscope (Cyscope ${ }^{\circledR}$ ) for malaria diagnosis. J Malaria Journal. 2010;9(1):1-4.

37. Bogoch II, Andrews JR, Speich B, Utzinger J, Ame SM, Ali SM, et al. Mobile phone microscopy for the diagnosis of soil-transmitted helminth infections: a proof-of-concept study. The American journal of tropical medicine hygiene. 2013;88(4):626-9.

38. Birhanie M. Comparison of Partec rapid malaria test with conventional light microscopy for diagnosis of malaria in Northwest Ethiopia. J Journal of parasitology research. 2016;2016.

39. Coulibaly JT, Ouattara M, Keiser J, Bonfoh B, N'Goran EK, Andrews JR, et al. Evaluation of malaria diagnoses using a handheld light microscope in a community-based setting in rural Côte d'Ivoire. J The American Journal of Tropical Medicine Hygiene

2016;95(4):831-4 .

40. Organization WH. Prevention and control of schistosomiasis and soil-transmitted helminthiasis: report of a WHO expert committee: World Health Organization; 2002.

41. Koydemir HC, Feng S, Liang K, Nadkarni R, Benien P, Ozcan A. Comparison of supervised machine learning algorithms for waterborne pathogen detection using mobile phone fluorescence microscopy. J Nanophotonics. 2017;6(4):731-41.

42. Holmström O, Linder N, Ngasala B, Mårtensson A, Linder E, Lundin M, et al. Point-of-care mobile digital microscopy and deep learning for the detection of soil-transmitted helminths and Schistosoma haematobium. Global health action. 2017;10(sup3):1337325.

43. Sowerby SJ, Crump JA, Johnstone MC, Krause KL, Hill PC. Smartphone microscopy of parasite eggs accumulated into a single field of view. J The American journal of tropical medicine hygiene. 2016;94(1):227-30.

44. Rosado L, Da Costa JMC, Elias D, Cardoso JS. Mobile-based analysis of malaria-infected thin blood smears: automated species and life cycle stage determination. J Sensors. 2017;17(10):2167. 
45. Slusarewicz P, Pagano S, Mills C, Popa G, Chow KM, Mendenhall M, et al. Automated parasite faecal egg counting using fluorescence labelling, smartphone image capture and computational image analysis. J International journal for parasitology. 2016;46(8):485-93.

46. LaBounty TM, Kim RJ, Lin FY, Budoff MJ, Weinsaft JW, Min JK. Diagnostic accuracy of coronary computed tomography angiography as interpreted on a mobile handheld phone device. JACC: Cardiovascular Imaging. 2010;3(5):482-90. 